\title{
Folie et dramaturgie dans les tragédies de Webster
}

\section{Rafik Darragi}

\section{(2) OpenEdition \\ Journals}

\section{Édition électronique}

URL : http://journals.openedition.org/shakespeare/1316

DOI : 10.4000/shakespeare.1316

ISSN : 2271-6424

Éditeur

Société Française Shakespeare

Édition imprimée

Date de publication : 1 novembre 1989

Pagination : 95-102

Référence électronique

Rafik Darragi, «Folie et dramaturgie dans les tragédies de Webster », Actes des congrès de la Société française Shakespeare [En ligne], 7| 1989, mis en ligne le 01 janvier 2007, consulté le 02 mai 2019. URL : http://journals.openedition.org/shakespeare/1316 ; DOI : 10.4000/shakespeare.1316

Ce document a été généré automatiquement le 2 mai 2019.

(c) SFS 
Folie et dramaturgie dans les tragédies de Webster

\author{
Rafik Darragi
}

